\title{
The Fraud Act 2006: has it had
} any impact?

\author{
by Ben Summers
}

The Fraud Act 2006, which represents the most radical change in the law of criminal fraud since the Theft Act 1968, came into force on January 15, 2007. We are now over a year into the new law, which seems a reasonable juncture to pose the question: has it had any impact?

\section{INTRODUCTION}

I t may simply be too early to tell what impact, if any, the Fraud Act 2006 has had; its provisions do not apply retrospectively, which means that only conduct which has taken place entirely since January 15, 2007 can be prosecuted under the new provisions. If we factor in the length of time which investigations and prosecutions typically take, it is obvious that the first major trials are only likely to be before the courts in the coming months. There is then a further delay, of course, until any cases are heard in the appeal courts, meaning there is a paucity of reported cases, as well as a significant delay in the publication of any useful prosecution and conviction statistics.

I would ask instead, what impact can the Act be expected to make? What are the problems and what were the solutions, both in theory and in practice, based on what little anecdotal evidence there is? I will therefore consider:

- problems with the "old" law;

- whether the Act can solve these problems;

- that case law under the Act which does already exist;

- prosecutorial attitudes towards the Act;

- defence perspectives on the Act; and finally

- other recent measures which may have an impact on fraud.

\section{THE OLD LAW}

The problems with the old law have been rehearsed many times before; the Fraud Act was the response to long and sustained criticism from the judiciary, practitioners and academics.

The overriding criticism of the law as it then stood was that there were too many specific fraud offences, defined with reference to different types of consequences and it was not always easy to identify which offence to charge, and often, even less easy to secure a conviction. This in turn led prosecutors, wherever possible, to a rely heavily upon the common law offence of conspiracy to defraud.

The specific nature of the law invited technical arguments. The prime example of the problem arose in 1996 when section 15 of the Theft Act 1968 (obtaining property belonging to another by deception) came under judicial scrutiny in the case of Preddy [1996] AC 815. The case concerned good old fashioned mortgage fraud in which the defendants had obtained mortgages from lenders on the basis of false representations.

The Court of Appeal held that where D dishonestly, and by deception, procured a transaction whereby V's bank account was debited and consequently there was a credit to D's account, D had not obtained property belonging to another by deception. The debt owed by V's bank to $\mathrm{V}$ had been extinguished, and what D obtained was a newly created debt owed by his bank to him, not property belonging to another. One chose in action had been extinguished and another created; although a chose in action is capable of being appropriated by another, here there were two separate legal rights, not a single piece of property. This is fine from a jurisprudential point of view and very neat logical thinking, but a disaster in Magistrates' and Crown Courts throughout the country.

The introduction of the new section 15A to the Theft Act 1968 by the Theft (Amendment) Act 1996 followed very swift consultation on the issue. Fears ran out across the legal and banking worlds that those "appropriating" bank balances were now immune from prosecution since no offence in the criminal calendar was able to tackle the behaviour. Section 15A, which created a new offence of obtaining a money transfer by deception, was intended to close the Preddy loophole, by removing the requirement to show that property "belonging to another" was obtained, in that as long as a balance was transferred as a result of the deception it did not matter that it was not the same legal property that was obtained. 
However, even this solution demonstrated the very problem from which our criminal law suffered, namely that piecemeal reform did nothing to tackle its over-technical nature and instead exacerbated the problem of too many, over-specific offences. For example, the 1968 Act had already been amended by the Theft Act 1978 which created new offences of obtaining services by deception, evasion of a liability by deception, and making off without payment. The Theft Act 1968 had itself been an attempt to codify and simplify a complex web of offences created by the Larceny Act 1916. It is almost as if legislators have a long and distinguished history of over-complication in this area.

There were also difficulties with charging attempts. D attempts to get a bank cashier to hand over money from an account; the cashier is suspicious and refuses: D does not during this stage of the process stipulate how he would like the transaction effected. Had the deception worked, and depending upon what $\mathrm{D}$ had intended to go on to say, the cashier could have either given cash, a cheque or transferred money between accounts. There was certainly an attempt, but of which offence?

The same could be said for conspiracies, although there are the authorities to the effect that an agreement to commit either one or another crime, although unlikely, is possible: Hussain [2002] 2 Cr App R 26.

All these were certainly issues, but the most acute problem which the Fraud Act 2006 was intended to remedy was the focus on the mind of the victim, rather than the mind of the offender. Under the old law it was necessary to prove that the deception had acted on the victim, for example that he/she would not have parted with the goods but for the deception. This increasingly created difficulties as technology developed and the use of credit cards and payment through machines or over the internet became prevalent.

If, for example, payment is made by credit card with the vendor receiving payment immediately from the card issuer, it may be that the vendor does not really care whether or not the purchaser had authority to use the card and does not give the matter any thought. Although the House of Lords held that it was possible to infer that the merchant did not wish to be a party to a fraud on the card issue, and therefore that the deception could be inferred (Charles [1977] AC 177 and Lambie [1982] AC 449), what would happen if the merchant gave evidence that he did not care? This was a tactic defence practitioners often deployed (myself included): cross examination of the victim to demonstrate that they gave no thought what so ever to the question of representations, express or implied, and therefore any misrepresentation did not "operate" upon their mind and hence the property was not obtained as a result of any deception.

There was also the problem that a machine, such as a ticket machine at a railway station, does not have a "mind", cannot think and therefore cannot be deceived: Holmes $v$ The Governor of Brixton Prison and another [2004] EWHC 2020.

A further problem resulting from the focus on the mind of the victim rather than the offender was that, although a failure to disclose may be as harmful and culpable as making a representation, it was difficult for prosecutors to successfully imply a representation from silence. People in positions of trust do not need to make false representations to get what they want. They can simply misuse what they have been entrusted with. A well known example is that of the manager of a pub who sold his own beer on his employer's premises; he was not guilty of theft and was not guilty of conspiracy to defraud, because he was acting alone: AG's Ref (No 1 of 1985) [1986] QB 491. However, two employees who sold their sandwiches in place of British Rail ones were guilty of conspiracy to defraud, as they acted together: Cooke [1986] AC 909. The law created an anomalous situation in which an act was capable of prosecution when carried out by more than one person, but not when carried out by someone acting alone.

Other problems included the fact that fraud (in the lay sense) is not always committed with an obvious view to gain. There was no offence of obtaining services without a deception, so jumping over a turnstile at a football match could not easily be charged. In addition to offences involving an element of deception or "fraud" in the everyday sense, the Fraud Act 2006 was also designed to deal with other specific lacunae in the existing law such as these. The offence of going equipped to steal only applied if the person was found with the necessary equipment outside their own home, meaning it was legal to have, for example, skimming devices at home. Fraudulent trading needed a corporate entity: there was a potential injustice where a fraudster sought to give the appearance that he was trading through a company but did not go through any of the formalities of acquiring one.

Having noted these elements of the Fraud Act 2006 I am afraid I must pass over them when considering whether the Act as a whole has had any impact of fraud and instead I will focus on fraud in the more everyday sense.

\section{PROBLEMS SOLVED?}

The new Act, which arises out of the Law Commission Report of 2002, goes back to the pre-1968 idea that it is not what the result of conduct is, or its effect on the victim, which is important, but rather the intention of the fraudster and what he/she actually did.

The Act repeals all the deception offences in the Theft Acts of 1968 and 1978 and replaces them with a single offence of fraud (s 1), with a maximum sentence of 10 years imprisonment, which can be committed in three different ways by: 
- false representation (s 2);

- failure to disclose information when there is a legal duty to do so (s 3); or

- abuse of position (s 4).

The idea of having one offence of fraud, which can be committed in three ways, seeks to sweep away the technicalities which beset the old law by capturing the base elements of fraud, but in a manner which is deliberately not attached to any specific activity. This is intended to overcome the difficulties as to charging and to "futureproof" the law, by avoiding over-specificity and allowing it to keep pace with developing technology.

In each case, the defendant's conduct must be dishonest and his intention must be to make a gain, or cause a loss or the risk of a loss to another. That is the sum total of the evidential requirements. Crucially, no actual gain or loss needs to proved.

The Act also creates new offences of possession of (s 6), and the making or supplying of (s 7), articles for use in fraud. By virtue of section 9, the offence of fraudulent trading (s 458 of the Companies Act 1985) will now apply to sole traders, partnerships and others "carrying on ... a business." Obtaining services by deception is replaced by a new offence of obtaining services dishonestly (s 11).

The Act does not abolish the common-law offence of conspiracy to defraud, despite the recommendation from the Law Commission that it should, on the basis that it was redundant in the light of the new general offences. It was retained for pragmatic reasons, in that it was considered at the time of the Act's Parliamentary passage that it might occasionally prove useful and could be the most effective charge where there were multiple defendants.

The new offence is inchoate in nature, so that what would have been an attempt under the old law becomes the complete s1 offence. This removes the problem associated with proving the causal link between the gain and the deception. Attempts under the new law are very narrow and turn on the particular facts: the offender must have made a mistake of fact, for example, making a statement believing it to be false, when it is in fact true. It is a triumph of intention over endeavour.

Having said all that, there are potential problems on the horizon already given the way in which the Act is drafted. The claim by Vera Baird QC, the Solicitor-General, that the Act was "already making a difference ... clarifying as it does for the first time what 'fraud' really means" seems somewhat puzzling, given that the Act does not in fact provide a definition of fraud and is extremely general in its terms. Nor does it define the meaning of "falsity."

There is an argument that the provisions of the Act are too general, and have the potential to extend criminal liability too far, criminalising lying and ignoring moral subtleties. There is the potential for trivial disputes to be elevated into criminal matters. Who are to be the gatekeepers? Policemen? Prosecutors? Magistrates? Jurors? Court of Appeal judges?

The section 2 offence seems likely to be capable of the most widespread use when charging, precisely because it is the broadest, but has it gone too far? For example, under section 2(5), a representation can arise before it is released from D's exclusive control, for example if he has typed a false representation into a computer, intending to send it later. He will still have an intention to gain, eventually, and so would be guilty of the full offence.

Another issue for consideration: unintentional falsity. By virtue of section 2(2) a statement will be considered false if "it is untrue or misleading" and "the person making it knows that it is, or might be, untrue or misleading." The often-quoted example of the section's breadth is that of an auction house selling a painting as an original, which later turns out to be a forgery. The art house genuinely believed that their attribution was correct, but was nevertheless aware that there is always a risk of error in such situations. Although the auction house would not have been guilty under sections 15 or 15A of the Theft Act 1968 of obtaining by deception, as it had taken reasonable steps and was therefore not reckless, it would be guilty of the section 1 offence under the new law. Again, the suggestion is that the requirement of dishonesty will work to sift out such marginal cases; indeed some say that the fact that dishonesty is the central battleground may be the most significant brake on the expansion of the offences.

Having said that, major worldwide auctioneers are concerned about this provision. The attitude that "dishonesty" is everything gives them little reassurance. What one art expert regards as dishonest may not necessarily be the same as another art expert, and even if they both agree that a particular description of an article is not dishonest from their expert point of view, who is to say that a jury would agree? How far does the auction house's obligation extend? What if one minority expert expresses a view about the authenticity of the particular piece or its provenance? Does the auction house have to bring this single opinion to the attention of potential bidders, in the face of all other academic opinion? If the auction house is aware of the opinion, is it dishonest not to refer to it? Is it dishonest to not look for other points of view even when there is consensus elsewhere?

Similarly, in terms of wide drafting, under section 6, it is merely possession of an "article" for use in fraud which is criminalised, not an article "made or adapted" for use in fraud. This could include possession of Microsoft Word, or even a pen and paper. I suspect that we all have about our person articles which could be "used in connection with fraud." When speaking at a seminar organised by barristers' chambers 3 Red Lion Court with Professor David Ormerod in 2007, we both voiced concern in relation to section 6. "Worry not," said David Levy, number two at the Fraud Prosecution Service (a specialist 
team within the CPS), "you can rely on the wisdom and discretion of prosecutors not to prosecute such trivial cases." I for one do not share his optimism, and in any event should we have offences on the statute book which are so absurdly drafted as to criminalise anyone carrying a pencil in their pocket?

Generally, there is a fear that there is too much pressure on the concept of dishonesty, which is not defined in the Act and is intended to follow the use of the Ghosh [1982] QB 1053 test in theft offences. Yet, in making its recommendations before the Bill was published, the Law Commission criticised the offence of theft as being almost entirely reliant on dishonesty as a concept. In that context, the introduction of more offences with exactly the same problem may seem odd.

The Ghosh test has faced sustained academic criticism, with an argument that it lacks legal certainty and is effectively retrospective, because it is left to the jury to consider the defendant's behaviour with the benefit of objective hindsight. Some say the approach is potentially contrary to Article 7 of the European Convention of Human Rights, although the Fraud Act has been confirmed as ECHR compliant by both the Home Secretary and the Attorney-General.

The concept of dishonesty has not previously been the subject of focused consideration in the context of fraud. It is likely that the test will require some judicial interpretation within the framework of the new offence. Given the scope of the new offences I wonder whether we will see a return to the pre-Ghosh authorities which required some sort of moral obloquy to underpin the “dishonesty." In the case law pre-Feely [1973] QB 530 the argument had succeeded that the absence of moral obloquy entitled the defendant to an acquittal. Feely put pay to that suggestion, but given the structure of the offences, will the Ghosh test survive unrevised? Is there a danger that the retrospective nature of the Ghosh test is capable of causing injustice in cases of particular practices/industries? Will the appeal courts have to intervene to exclude from the offences' reach behaviour which "everyday standards" might stigmatise as "dishonest", but which in the particular circumstances of the case are not morally culpable? Consider an over-zealous sales puff which nobody takes seriously: it might be Ghosh "dishonest" but should it really amount to fraud?

Not all comment is in the direction that the Ghosh test is flawed. Some argue that such an approach allows for the flexibility necessary in a jury system: it allows for us to be judged by our peers. If, according to their everyday standards, a jury considers certain behaviour to be dishonest (and in those circumstances, in the absence of some particular factor affecting the cognitive functioning of the defendant, it is hard to see why he/she should not also know that), then is that not jury trial par excellence? Is what some see as inconsistency actually flexibility, which allows justice to be done in each particular case?

\section{THE EMERGING CASE LAW}

For the reasons I outlined earlier, only two reported cases have been decided under the Act, each of which turns on very specific facts. If the design of the Act is achieved, this may well remain the case; the simplicity is intended to move the law away from the technicalities and arguments which have dogged the old offences. Somehow, I doubt it will succeed.

The first reported case is Kensington International Limited $\checkmark$ Republic of Congo and others [2007] EWCA Civ 1128, a decision in the Civil Division of the Court of Appeal, given on November 7, 2007, which gives guidance on the scope of section 13 of the Act. The claimant had judgments in the Commercial Court for over US\$1 10 million against the Republic of Congo, but was unable to enforce them because Congo does not maintain substantial assets abroad. Instead the claimant obtained various orders enabling it to intercept monies due to be paid by UK companies (joined as defendants to the proceedings: companies in the Vitol group) to Congo on contracts to purchase and export crude oil.

The UK companies sought to rely on the privilege against self-incrimination in the proceedings, arguing that in giving evidence to the court to overturn the orders they and their principals would be exposed to prosecution for offences of bribery (the common law offence, the Public Bodies Corrupt Practices Act 1889 and the Prevention of Corruption Act 1906). However, section 13(1) of the Fraud Act 2006 provides that:

"A person is not to be excused from -

(a) answering any questions put to him in proceedings relating to property, or

(b) complying with any order made in proceedings relating to property, on the ground that doing so may incriminate him or his spouse or civil partner of an offence under this Act or a related offence."

Sub-section 2 goes on to provide that any answers shall not be admissible in evidence in criminal proceedings against the maker and sub-section 4 provides that "related offence" means conspiracy to defraud (the common law offence which remains good law notwithstanding the new offences) and "any other offence involving any form of fraudulent conduct or purpose.”

The UK companies mounted various arguments, including the contention that corruption offences were not "related offences" since they did not involve "any fraudulent conduct or purpose" and that therefore they were not afforded this statutory protection and instead could rely upon the general privilege against selfincrimination. 
The court rejected that argument and decided that corruption was a "related offence" in that, although the case law demonstrated that dishonesty "as such" did not need to be proved, the word "corruptly" signifies that the circumstances in which the gift was given were such that it had a tendency to corrupt, that is, "to suborn the agent to disregard his duty and act contrary to the interests of his principal, thereby causing him harm." Therefore, the court concluded, "offering a bribe with the intention that it be accepted and acted upon involves a form of fraudulent conduct, or at any rate of fraudulent purpose."

The court took an expansive view of the meaning of "fraudulent" and was prepared to include bribery offences within this definition, notwithstanding long settled case law that provided that bribery offences do not involve an element of dishonesty. Although confined on its facts to the ambit of section 13 of the Act, the case demonstrates that the court was prepared to re-visit well established principles in the light of the new framework. This of course has the potential to lead to inconsistent decisions in that this case seems to establish that, although the new fraud offence requires dishonesty to be proved, you do not need to be dishonest to be fraudulent!

The only other reported case I have been able to identify is Attorney General's Reference (No 6 of 2008) [2008] EWCA Crim 677. This is the first sentencing appeal to arise from the Act and involved conjoined cases of the possession of false identity documents. In one of the appeals, a failed Zimbabwean asylum seeker, who could not be deported due to political pressure on the government, but was unable to work in the UK and was unaware of his right to claim subsistence vouchers, purchased false identity documents in order to obtain menial employment. In those extraordinary circumstances, the court upheld a sentence of six months imprisonment suspended for two years, with a requirement that the offender undertake 80 hours of unpaid work for the community

It is worth noting that the maximum sentence has risen by nearly 50 per cent from to 7 years to 10 . That would result in the existing average sentence for fraud offences increasing from 3 years to 5 . Reference was made to existing guideline authorities for possession of forged identity documents and so it appears that the fact of a charge under the Act made little difference to the sentence imposed.

If and when you come to read the case you may be able to resolve a puzzle. The judgment refers to charges under section 51 of the Fraud Act 2006; a puzzle because the Act is commendably succinct and runs to only 16 sections. Did the court mean to refer to the section 6 offence of possession of articles for use in fraud?

\section{PROSECUTORIAL ATTITUDES}

Unsurprisingly, the Act was generally welcomed by prosecuting authorities. It is perceived that substantive fraud offences have several practical trial advantages, making them easier, and quicker (cheaper), to investigate and prosecute successfully, and ultimately lessening the chances of a successful appeal. If few major trials have yet to come to court, it does appear that the new law is being used routinely in the Magistrates' and Crown Courts for small-scale offending. According to the Solicitor-General, the Act has also been welcomed by the police, who are "reporting that the new offences are easy to understand and more closely reflect real fraud activity."

Unofficial figures from the CPS indicate that there has been a 40 per cent increase in fraud related prosecutions, a 10 per cent increase in the conviction rate and there are more guilty pleas in "volume fraud" (small scale but repeated offending rather than large scale fraud). At the higher end of the scale the SFO reports that it has only one active case which may involve Fraud Act offences.

However, there is a sense among prosecutors that the reality may not be entirely living up to the theory. As there do not need to be any consequences from the conduct for the new offences to be made out, it will often not technically be necessary to call evidence from a victim. This obviously has the potential to simplify the job of the prosecutor and shorten the length of a trial. However, the feeling seems to be that this approach may cause presentational difficulties with a jury, who will expect to hear from someone who has suffered as a result of the crime; the concept of dishonesty in the absence of a loser may be a hard one to "sell" to the jury. It is also at odds, it might be noted, with the government's drive to persuade the public that fraud should not be considered a "victimless" crime (consider the comments of the new Director of the SFO, Richard Alderman, reported in Accountancy Age on May 15, 2008).

It may therefore still be tactically preferable to prove that a victim has suffered a loss. The defence will, in any event, be able to request the evidence of a victim, in order to attempt to challenge it and thereby disprove dishonesty. Consider the Jubilee Line case in which the prosecution did not adduce evidence of gain or loss in its case of conspiracy to defraud; the defence invited the prosecution to gather such evidence contending that it went to the question of the defendants' intentions. When it was not produced, the defence argued to the jury that its absence demonstrated the lack of intent to cause a loss or gain and therefore an absence of dishonesty.

There is also the fact that the existence and extent of any consequences of the fraudulent conduct will be central to the sentencing exercise, as well as to compensation and confiscation orders: a victim who is not named on an indictment or in an offence taken into consideration cannot be compensated by the court. This means that it will still be necessary in many cases to gather this evidence. The Sentencing Guidelines Panel is currently considering 
how sentencing judges should approach cases in which there is no evidence of loss or gain.

There is also a feeling among prosecutors that the use of substantive fraud counts may not be able to adequately reflect the totality of offending in complex cases. This comment has been made at recent lectures by members of both the Attorney-General's Office and the Serious Fraud Office. The common law conspiracy to defraud charge will therefore still be attractive and is likely to be continued to be used; indeed anecdotal evidence from defence practitioners is that there has been no diminution in the use of the common law offence at the charging stage. On any analysis of the statistics, this charge results in a relatively lower number of convictions. While this may be a good thing for the defence, it seems to go against the general desire for efficiency which lies behind this Act.

An interesting point of reference in this context is the CPS guidance to prosecutors, found on its website (www.cps.gov.uk/legal/section8/chapter_d.html). It is clear from the guidance that the CPS is aware of potential difficulties with the Act, for example the criminalising of "trade puffs" and possible attempts to use the legislation to settle what are effectively personal or commercial disputes. It states that, when considering the public interest test, the borderline between criminal and civil liability "is likely to be an issue."

Where prosecutors have a choice between a charge under the Act and a charge under the Theft Act, as may regularly be the case, it seems likely that the former will often be preferred. The thrust of the guidance is that a simpler charge is always better, and that the Fraud Act is generally simple, notwithstanding the difficulties raised above, because it focuses only on conduct. Thus, a person who has stolen from their employer is more likely now to be charged with fraud by abuse of position, rather than theft by an employee.

\section{DEFENCE PERSPECTIVE}

In my view, there is a very real practical significance for the defence practitioner in the Act's reliance on dishonesty.

It will be more difficult to advise clients to enter a plea of guilty, as there is often a "chance with a jury" on dishonesty; the Act may militate against guilty pleas, which runs contrary to the government's desire for speedier and more efficient justice. It is a good point in mitigation to say to a judge that it is impossible for legal advisors to give definitive advice to a client in cases in which the only issue is whether the accepted conduct is dishonest. Who can predict with certainty the view the jury will take? In those circumstances is the client not entitled, just as the judge is, to leave dishonesty to the jury?

However, the reluctance of appeal courts to overturn convictions in which the jury made a finding of dishonesty is well-established. That train of thought leads to this: will it be better in some cases not to have a jury but instead have a judicial tribunal of fact (for example in the stereotypically unpopular professions)? I am not going to list them for fear of giving offence, but another area in which trial by judge alone might be attractive is where there has been widespread critical press coverage in a case such as the SFO investigation of BAe and the Al-Yammah contract. I will return to juryless trial later in this article.

Another practical issue for defence practitioners is whether there will be a need for expert evidence on practices within a particular profession, to counteract the allegation of dishonesty, thereby prolonging trials. The auction house I discussed earlier is an example. If the capacity for expert evidence to lead trials into complex corners of particular expertise requires demonstration, may I commend to you the extraordinarily learned first instance judgment of Jack J in Thomson ${ }_{v}$ Christie Manson \& Woods Ltd [2004] EWHC 1001 (QB) which concerns the provenance of a pair of Louis XV porphyry and gilt-bronze vases.

One more point for consideration - should defence practitioners encourage use of conspiracy to defraud, which has a relatively low conviction rate?

\section{OTHER MEASURES TO COMBAT FRAUD}

Fraud is a massive and constantly growing problem. According to figures from the Association of Chief Police Officers for 2007, its cost including detection and prosecution is estimated to be approximately $£ 20$ billion a year, or around $£ 330$ for every person in this country. It is obvious then, that the Fraud Act cannot be expected to solve the problem on its own. The Home Office reports that 79 per cent of prosecutions for fraud and forgery offences result in a conviction, but only 10 per cent of such recorded offences are ever actually prosecuted (making a conviction rate of 8 per cent for recorded offences, which in turn are just a drop in the ocean of all frauds). The reality is that it is not the legislation, but a lack of resources at an investigatory level which is the real issue; in that context, the impact of this Act, or any Act, will be limited.

\section{Government Fraud Review}

The Government has recognised the problem and the Government Fraud Review was commissioned by the Attorney General in October 2005. The final report, which contained some 62 recommendations was published in July 2006 and the government then published its formal response in March 2007. Its conclusion was that antifraud work is fragmented and lacking in co-ordination.

\section{National Anti-Fraud Strategy}

The principal recommendation of the Government Fraud Review was the National Anti-Fraud Strategy. This is intended to herald a change of attitude, making the country a hostile environment for fraud, and a move 
towards a more pro-active and co-ordinated approach to the prevention and investigation of fraud. Some $£ 29$ million of government funding has been allocated, which is perhaps relatively modest if the scale of problem is considered. There are three central "building blocks" to the strategy:

- The National Fraud Strategic Authority (NFSA) will be set up, to supplement the efforts of existing organisations, co-ordinating the fight against fraud.

- The National Fraud Reporting Centre and Intelligence Bureau (NFRC) will also be created, as a central contact point for receiving and analysing reported cases of fraud. This should become fully operational in 2009 and the intention is that it will allow patterns in offending to be identified which cannot not be spotted at a local level, resulting in a better allocation of resources.

- A National Lead Force for Fraud has also been created, a role which will be taken on by the City of London police.

\section{Serious Crime Prevention Orders}

The Serious Crime Act 2007, which commenced on April 62008 , introduced the concept of Serious Crime Prevention Orders - the so called "super ASBOs." In essence, these are civil orders, similar to injunctions, which restrain serious and serial offenders' business and commercial activities. They are available to a Crown Court on either conviction or committal for sentence and can be used for convictions under sections 1, 6, 7, 9 and 11 of the Fraud Act (as well as for conspiracy to defraud). The first orders were served in Northern Ireland on April 22, 2008, on four people who were the subject of a HM Revenue \& Customs prosecution for revenue evasion in relation to fuel fraud.

\section{The Financial Court}

Another recommendation of the Fraud Review was the establishment of a Financial Court jurisdiction, so that the different proceedings arising from serious fraud cases, both criminal and civil, can be brought together in one court. This would not be a new institution as such, but would involve extending the jurisdiction of the High Court to create a "virtual" court sitting in existing courtrooms and using a specialist group of judges who have experience of, and familiarity with, financial issues and well developed case management skills. They would be drawn, not just as now from Crown Court judges (with presiding High Court judges taking an occasional fraud case), but also from amongst High Court judges more generally: from the Commercial Court, its mercantile judges and possibly even from the Chancery Division.

This proposal is currently being considered by a working group, with the aim of producing a full cost/benefit study by spring 2009. The practical issues relating to the proposal are legion, so the working group's recommendations will be important to consider. As alluded to earlier, if the idea can be translated into working practicality there may be circumstances in which the fraud defendant might welcome the jurisdiction of the Financial Court, enabling him/her to resolve in an efficient and consistent way the criminal allegations and civil claims which almost inevitably follow corporate collapse.

\section{Plea bargaining}

On April 3, 2008, the Attorney-General's office launched a consultation on the Introduction of a Plea Negotiation Framework for Fraud Cases in England and Wales. The consultation arose out of one of the recommendations of the Fraud Review, which identified advantages in offering parties to fraud cases the opportunity to reach a courtsanctioned agreement at an early stage.

In England and Wales, informal post-charge discussions between the prosecution and the defence already take place, with varying degrees of success. There is also the system of "Goodyear" indications, in which defendants can receive an indication of their likely sentence from the judge before entering a guilty plea.

This differs from the formal system which exists in the US and of which the recent Marine Hose case is an example. In this case of cartel behaviour affecting the US and UK markets the defendant was able to negotiate a fixed sentence with US Department of Justice prosecutors in advance of entering a formal plea in the US. He was then able to return to the UK, the sentence in the US being suspended upon condition that it would not be activated if, following a guilty plea in the UK, the sentence passed here was equal to or in excess of the US sentence. This would allow the defendant to serve his sentence in the UK and avoid two prosecutions. Quite how the defence will present the case to a Crown Court judge when mitigating ("you must sentence the defendant to at least four years ...") remains to be seen, but clearly this coordinated approach to sentencing has advantages for defence and prosecution alike.

The consultation sets out a framework for plea negotiation whereby the parties enter into voluntary precharge discussions with a view to agreeing a basis of plea. It envisages discussions taking place on the presumption that nothing said by the suspect could be used against him in any subsequent proceedings (although a written agreement to the contrary would be possible). Prosecutors are expected to comply with their disclosure obligations on a voluntary basis as the statutory obligations set out in the Criminal Procedure and Investigations Act 1996 are not triggered until after charge. The framework includes guidelines for prosecutors on when to accept a guilty plea. If accepted, the basis of plea would then be recorded in a written plea agreement to go before the Crown Court at the defendant's first appearance. The judge could accept or reject the agreement or defer a decision pending further 
information; he/she could also give an indication of a maximum sentence.

The consultation ended on June 26, but the proposals have already attracted criticism and there have been questions as to whether the framework is actually in the public interest. Of particular importance is that, as drafted, the framework does not differentiate between corporations and individuals. This means that the unavailability of legal aid pre-charge could leave unfunded individuals in a position where they do not have access to independent legal advice.

The FSA is among the prosecuting authorities which have long been pushing for plea-bargaining in this country, as it believes, for example, that only by securing evidence from those inside the ring will it ever be able to secure convictions for insider trading. There is a view that pleabargaining would allow it to reduce the length of cases, therefore freeing up resources and meaning more cases can be pursued, whilst lessening the strain of such proceedings on victims and witnesses. It must also be the case that there is a hope it will secure convictions in cases where the success at trial is by no means certain.

However, there are some doubts as to whether pleabargaining in this country can actually achieve all this. The realities of the UK justice system are very different to those of the US, not least because of the sentencing regime and the availability of public funding. There will be a carrot but no stick, and it is hard to envisage the system resulting in, as it does in the US, people "coming clean" to the authorities without some sort of push. In addition, given that the new offences hang so much on dishonesty, which is a jury issue, it may be, as suggested above, that individuals are still prepared to take their chances on remaining silent.

\section{Criminal Justice and Immigration Act 2008}

The Serious Fraud Office has compulsory powers under section 2 of the Criminal Justice Act 1987 to compel the disclosure of evidence that may be relevant to a current investigation into serious or complex fraud. The Criminal Justice and Immigration Act, which received Royal Assent on May 8, introduces a new section 2A into the 1987 Act, which allows the director of the SFO to approve the use of section 2 powers at the vetting stage in cases where it appears that there may have been a corruption offence involving a foreign official.

In practice, the provision will allow the SFO to compel British companies and individuals to provide evidence about possible corruption abroad, as long as the material is in the United Kingdom. It is said that corruption abroad is particularly hard to investigate, as not only are the potential witnesses many hundreds of miles away and reluctant to come forward, but the foreign jurisdiction may well be unable and unwilling to provide information. The SFO cannot justify commencing a formal investigation without sufficient information on which to make a decision as to whether or not such a use of its resources is justified, and so foreign corruption cases often do not get beyond the "vetting stage."

The Law Commission is currently considering the law of bribery (although the consultation period has now closed). The proposals are interesting and I suspect represent the best route forward to reaching a consensus between the interested parties. I hope that we will see progress, which has been promised since the Law Commission produced its first proposals in 1998. I do not have time to consider these proposals in any depth here (there is a paper on our website), but in the context of my topic, it is interesting to note that the proposals make no reference to investigative powers but do deal with the requirement of consent to prosecute, which is a related but separate issue. The consultation paper, which is worth reading in full, also demonstrates the overlap between what might in lay terms be considered as corruption and the fraud offence under the Fraud Act. It remains to be seen whether a newly drafted corruption offence will overlap with the Act.

\section{Trials without jury}

The Fraud (Trials Without a Jury) Bill, which sought to amend section 43 of the Criminal Justice Act 2003, had its second reading in the House of Lords on March 20, 2007. It was voted down by the Lords on that occasion and has not been resurrected. Section 43 of the CJA 2003 allowed a defendant to elect trial by Crown Court judge alone; the Bill was drafted to amend the Act by requiring a High Court judge rather than a Circuit judge to sit in the Crown Court in such cases; this was seen as a "softener", but failed to curry favour with those who oppose trial without jury.

It appears that the government has dropped the plans to pursue juryless trials in complex fraud cases. If and when we have a change of government, expect this issue to resurface. The power is on the statute book, but like so many reforms in recent years has never been enacted.

\section{CONCLUSION}

Although there is plenty to consider in relation to the prosecution of fraud, in response to the question I have posed as to whether the Fraud Act has had any impact, I am afraid my answer has to be that "it is still too early to tell". A Home Office review of the operation of the Act is due three years after its implementation, so if I am asked again in 2010, I may have a better chance of answering the question.

One final thought: if it is right that the Fraud Act turns out to be an improvement upon the old law theoretically, but in practice has little impact, is that a result of our system rather than the black letter law? A development which I believe may be capable of producing a fundamental shift in the punishment of fraud carried out in the commercial/business sector is Part 3 of the Regulatory Enforcement and Sanctions Bill currently making its way through Parliament. This is a topic worthy of its own 
article, but I invite you to look at it and the reports which proceeded it, the Hampton Review in 2005 and the Macrory Review in 2006.

The Bill heralds a new enforcement regime of civil sanction rather than criminal trial (save in the worst cases); it is clear the Government has a jealous eye on the revenue creation enforcement actions of the Department of Justice and Securities Exchange Commission in the United States. Although the SFO and CPS do not feature in Schedule 5 to the Bill, the regulators to be given the new civil powers of enforcement, the Financial Services Authority, the Office of Fair Trading, the Health and Safety Executive and the Environmental Agency are among the prosecutors which do. We may be witnessing a movement away from the criminal law as the primary method of regulating conduct in commerce, in which event legislative changes such as the Fraud Act may, over time, have less and less effect.

- This article is taken from a lecture delivered at the Institute of Advanced Studies on May 14, 2008.

Ben Summers

Partner, Peters \& Peters

bsummers@petersandpeters.com

\section{Institute Events}

Friday, 31 October 2008, 9.0am

One day conference

Control of national resources: the challenges for international dispute resolution

Speakers drawn from the IDR group and will include:

PRINCE BOLA AJIBOLA, PROFESSOR AHMED EL KOSHERI, JOHAN GERNANDT, DAVID BRANSON

Chairs will include: RT HON LORD ANDERSON OF SWANSEA DL, SIR HENRY BROOKE, SIR ANTHONY EVANS

This one-day conference will look at three topics: 1 . The issue of resource nationalism 2. Whether "good offices" can assist in relation to resource nationalism 3. Whether established international dispute resolution bodies have a role to play in resolving disputes between resource - rich countries and consuming countries: Can these traditional "western" bodies satisfy non-western countries that they will receive a fair and unbiased hearing?

\section{Wednesday, 5 November, 9.15am \\ One day conference \\ Socio-legal studies and the humanities}

Keynote speaker: MELANIE L WILLIAMS

Professor of Literary Jurisprudence, School of Law, Exeter University, with PROFESSOR PENNY BOOTH, Staffordshire University; DR LORIE CHARLESWORTH, Liverpool John Moores University; MARC COEN, Trinity College Dublin; PROFESSOR KATE NACE DAY and PROFESSOR RUSSELL G MURPHY, University of Suffolk; DR WOUTER DE BEEN, VU University, Amsterdam; DR PENNY ENGLISH, Anglia Law School; ALEXANDRINE GUYARD-NEDELEC, University of Paris, Diderot; PROFESSOR ERIC HEINZE, Queen Mary, University of London; ROBIN LISTER, University of Bradford; DR STEFAN MACHURA, Bangor University; DR EUGENE MCNAMEE, University of Ulster; DR JUDITH ROWBOTHAM, Nottingham Trent University; ALECIA SIMMONDS, University of Sydney, Australia; MEGAN WACHSPRESS, University of California, Berkeley; GARY
WATT, University of Warwick; DR STUART WEINSTEIN and DR CHARLES WILD, University of Hertfordshire; ROGER WELCH, University of Portsmouth

This one day conference is being hosted by the Socio-Legal Studies Association with support from the Institute of Advanced Legal Studies.

Tuesday, 11 November, 9.30am

One day conference

The Pinochet case and its consequences ten years on

Sponsored by: The British Institute of International and Comparative Law; Centre for Law and Society at Lancaster University; Institute of Advanced Legal Studies and Institute for the Study of the Americas, School of Advanced Study, University of the London; JUSTICE (the British Section of the International Commission of Jurists).

Participants will include:

\section{PROFESSOR LAURA BIANCHI}

Lawyer representing victims in the Italian judicial investigations of crimes committed by Pinochet against Italians

\section{DR JIMMY BELL}

Chilean exile and human rights activist

\section{SIR GEOFFREY BINDMAN}

Solicitor, who acted for Amnesty International and others in the Pinochet case

\section{REED BRODY}

Counsel and Spokesperson, Human Rights Watch; coordinated Human Rights Watch's intervention in the House of Lords and is co-author of "The Pinochet Papers: The Case of Augusto Pinochet in Spain and Britain"

\section{DR JUAN E GARCÉS}

legal team coordinator for the Spanish case against Pinochet

\section{CHRISTOPHER HALL}

Senior Legal Adviser, International Justice Project, Amnesty International

All events take place at the Institute of Advanced Legal Studies except where otherwise indicated. Lectures and seminars free unless specified. CPD accreditation is provided with many events. For CPD and all other enquiries contact Belinda Crothers, Academic Programmes Manager, IALS, 17 Russell Square, London WC1B 5DR (tel: 020 7862 5850; email: IALS.Events@sas.ac.uk). See also our website for further information (http://www.sas.ac.uk/events/list/ials_events). 